\title{
Effects of natural compounds in treatment and prevention of hepatotoxicity and hepatocellular carcinoma
}

\author{
Mohamed A. Hamzawy ${ }^{1}$, Ezzeldein S. M. El-Denshary'ㄹ, Mosaad A. Abdel-Wahhab ${ }^{3}$ \\ ${ }^{1}$ Department of Pharmacology and Toxicology, College of Pharmacy, Misr University for Science and Technology, \\ 6th of October City 15525, Egypt \\ ${ }^{2}$ Department of Pharmacology and Toxicology, Faculty of Pharmacy, Cairo University, Cairo 11562, Egypt \\ ${ }^{3}$ Department of Food Toxicology and Contaminants, National Research Centre, Dokki, Cairo 12622, Egypt
}

\begin{abstract}
Liver diseases are most common disorders in the world and characterized by rapid changes from steatosis to chronic hepatitis, fibrosis, cirrhosis, and hepatocellular carcinoma (HCC). Natural products that attained great attention is to be used in the prevention and treatment of multiple diseases in humans. Several researches have been reported numerous natural and phytochemical compounds that may counteract or prevent the hepatic injury and primary liver cancer. The conservative treatment of liver toxicity and HCC may face awkward challenges in chemotherapy such as therapeutic failure or drug resistance. Accordingly, there is an actual need for safe and effective therapeutic and preventive modalities for liver disorders. The present review aims to focus on the potential protective and therapeutic effects of natural compounds in the prevention and treatment of hepatotoxicity and HCC. It also demonstrates the mechanism of the natural products in enzymatic regulation of antioxidants and its role in apoptosis and proliferation of cancerous lesions of hepatocytes. Accordingly, it highlights the promising role of natural bioactive compounds and provides the rational for further transitional researches, and emphasize on the scientific validation of natural compounds for therapeutic portfolio for clinical use in liver diseases.
\end{abstract}

Key words: Antioxidant; hepatocellular carcinoma; hepatotoxicity; liver; natural compounds

\section{Address for correspondence:}

Prof. Mohamed A. Hamzawy, Department of Pharmacology and Toxicology, College of Pharmacy, Misr University for Science and Technology, P.O. Box: 77, 6th of October City 15525, Egypt. E-mail: hamzawymohamed@gmail.com

Received: 20-07-2015, Accepted: 23-09-2015

\section{INTRODUCTION}

Chronic liver diseases are common worldwide disorders characterized by bad sequels started with steatosis to chronic hepatitis, fibrosis, cirrhosis, and hepatocellular carcinoma (HCC). ${ }^{[1,2]}$ Indeed, HCC is the fifth most commonly leading cancer, the major cause of death in patients with liver cirrhosis, and the second common cause of cancer-related death in the world..$^{[3]}$

\begin{tabular}{|l|c|}
\hline \multicolumn{2}{|c|}{ Access this article online } \\
\hline \multirow{2}{*}{ Website: } & Quick Response Code \\
http://www.hrjournal.net/ & \\
DOI: & \\
10.4103/2394-5079.167378 & \\
\end{tabular}

The major target strategy in the treatment of liver diseases is to terminate the serial consequences at the pre-fibrotic stage of the liver. ${ }^{[4]}$ To date, modern medicines have little to offer for alleviation of hepatic diseases. However, natural-based preparations are successfully employed for the treatment of liver disorders. ${ }^{[5]}$ Accordingly, there is an increased attention in natural products that may counteract

This is an open access article distributed under the terms of the Creative Commons Attribution-NonCommercial-ShareAlike 3.0 License, which allows others to remix, tweak, and build upon the work non-commercially, as long as the author is credited and the new creations are licensed under the identical terms.

For reprints contact: reprints @medknow.com

How to cite this article: Hamzawy MA, El-Denshary ES, Abdel-Wahhab MA. Effects of natural compounds in treatment and prevention of hepatotoxicity and hepatocellular carcinoma. Hepatoma Res 2015;1:111-8. 
the detrimental effects of environmental or chemical toxic compounds and prevent multiple hepatic disorders in humans. ${ }^{[6]}$

\section{POLYPHENOLS}

Polyphenols, commonly presented in vegetables, herbs, seeds, fruits, and other natural sources, represent more than 8,000 different compounds, classified in different classes based on their chemical structure, they are composed of at least one aromatic ring with one or more hydroxyl groups attached. ${ }^{[7]}$ Polyphenols may be a promising candidate for preventing ethanol-induced liver injury through regulating alcohol metabolic enzymes in a cyclic AMP-dependent manner, polyphenols play a crucial role in the protection of liver against hepatitis due to its potential activity in the reduction of early proinflammatory cytokines [tumor necrosis factor- $\alpha$ and interleukin (IL)-1 $1 \beta]$, activation of anti-inflammatory IL-10, and inhibition of lipopolysaccharide-induced activation of nuclear factor kappa B (NF-KB) in hepatocytes. ${ }^{[8]}$ Polyphenols are composed of two formulas; phenolic acids and flavonoids and account for $60 \%$ and $30 \%$, respectively, of dietary polyphenols. ${ }^{[9]}$

Phenolic compounds (PhCs), which are ubiquitously found in plants, have a potent antioxidant activity mainly due to their ability in redox reactions, so they act as reducing agents, singlet oxygen quenchers, hydrogen donators, and chelating agents of metal ions. ${ }^{[10]}$ Moreover, previous studies revealed that $\mathrm{PhCs}$ played an important role in the prevention of hepatotoxicity through increase in the level of reduced glutathione (GSH).[11]

Flavonoids are a group of polyphenolic compounds, different in chemical structure and characteristics, naturally founded in plants. More than 9,000 different flavonoid compounds were described in plants till now and they play major biological roles through affecting several developmental and important processes.

Flavonoids showed versatile health benefits such as anti-inflammatory, antioxidant, anti-proliferative and anticancer activity, free radical scavenging activity, and antihypertensive effects..$^{[12]}$ It has been reported that one of the flavonoid compounds luteolin showed a hepatoprotective effect and antioxidant properties against methanol hepatotoxicity. ${ }^{[13]}$

\section{HERBAL AGENTS}

Milk thistle (Silybum marianum) is one of the most famous herbal agents used to treat liver diseases since the 16th century.
Major constituents of milk thistle are the flavonoids, such as silibinin, silidianin, silichristin, and isosilibinin. ${ }^{.14]}$ Silymarin showed antioxidant properties and hepatoprotective activity, through inhibition of lipid peroxidation, depletion of liver GSH, inhibition of genotoxicity, and enhancement of hepatogenesis. ${ }^{\mid 15]}$

Glycyrrhizin, the active constituent obtained from aqueous extraction of the liquorice root (Glycyrrhiza glabra), has been used in traditional medicine to alleviate bronchitis, gastritis, and jaundice. The major constituents of licorice are glycyrrhetic acid, flavonoids, hydroxycoumarins, and beta-sitosterol. The latter is likely possessing glucocorticoid and mineralocorticoid properties. ${ }^{[16]}$ Licorice and their products have been reported to be useful in the treatment of human hepatitis, animal inducible hepatocarcinogenesis, and attenuating titanium dioxide nanoparticles-induced hepatotoxicity. ${ }^{[17,18]}$

Ginseng (Panax ginseng), a valued Chinese and Korean traditional medicinal herb, has been clinically used in China for thousands of years. Red ginseng elicits a protection against aflatoxin $\mathrm{B}_{1}$ and fumonisins-induced hepatic pre-cancerous lesions in rats and synergistic action with honey against $\mathrm{CCl}_{4}$-induced hepatonephrotoxicity. ${ }^{[1,20]}$

Ginkgo biloba extract has been shown antioxidant property due to its ability to scavenge free radicals and inhibition of lipid peroxidation. ${ }^{[21]}$ The most recent discovered G. biloba components are polyphenols from which flavonoids and terpene lactones were derived and widely used for treating cardiovascular, non-alcoholic fatty liver, and cerebrovascular diseases. ${ }^{[22-24]}$

Dandelion (Taraxacum officinale), dandelion water extract (DWE), a herbal medication, may have an effect on the activity of messenger RNA expression of hepatic antioxidant enzymes due to its components that includes sesquiterpene lactones, phenylpropanoids, triterpenoid saponins, and modify lipid profile in streptozotocin-induced diabetes in rats. ${ }^{[25-27]}$ It has been reported that DWE has anti-fibrotic effect through inactivation of hepatic stellate cells (HSCs) and the enhancement of hepatic regenerative capabilities. ${ }^{|28|}$

Garlic (Allium sativum) has been widely used as a foodstuff and a traditional medicine for many centuries throughout the world. Garlic is available in different forms such as powder or garlic oil. Garlic has a beneficial value such as anti-atherosclerotic, antihypertensive, antimicrobial, anticancer, immunomodulatory, antioxidant, and radioprotector effects. ${ }^{[29]}$ On the other hand, allicin (diallyl thiosulfonate), which is the main biologically active 
component of freshly crushed garlic cloves, has been produced by the interaction of the non-protein amino acid alliin with the enzyme alliinase (alliin lyase). It has anti-hepatocarcinogenic effect through the p53 gene modulating apoptosis and autophagy. ${ }^{[30]}$

Turmeric (Curcuma longa) has been found in the Far East and tropical regions. It had been used to treat menstrual disorders, colic, inflammation, bruising, dyspepsia, hematuria, and flatulence. It also has anticancer and antioxidant actions due to the presence of three chemical components, for example, curcumin I, II, and III. ${ }^{[31]}$ It suppresses the activation of NF- $\kappa B$, so it may be useful in preventing liver disease such as hepatonephrotoxicity. ${ }^{[32]}$

Colchicine (Colchicum autumnale) is the major alkaloid obtained from C. autumnale. Pharmacological properties of colchicine included antimitotic effects and can be used for the treatment of gout. ${ }^{[33]}$ Moreover, colchicine has been acting as an anti-tumor agent. ${ }^{[34]}$ Colchicine has been reported to be a safe anti-fibrotic agent when used for long-term treatment of liver disease. ${ }^{[35]}$

Thyme (Thymus vulgaris) is cultivated in Central and Southern Europe, Africa, and Asia. It is rich with essential oils and anti-oxidative phenolic substances. ${ }^{[36]}$ It is widely used in folk medicine for the treatment of a variety of diseases including gastroenteric and bronchopulmonary disorders. It is also effective as anthelmintic, antispasmodic, carminative, sedative, diaphoretic, antimicrobial, antioxidant, and antifungal agents. ${ }^{|37|} T$. vulgaris also showed hepatorenoprotective effects against aflatoxicosis in rats. ${ }^{[38]}$

Marigold (Calendula officinalis) is an annual herb native to the Mediterranean region. In Europe and America, it is cultivated for ornamental and medicinal purposes. C. officinalis as the marigold or maravilla has been widely used in folk therapy. Calendula flower decoction or tincture showed more than 35 properties and its preparations have been used as valuable remedies for burns. C. officinalis is mainly used for cutaneous and internal inflammatory diseases of several origins. ${ }^{[39]}$ Its extract has a protective effect against ultraviolet-induced oxidative stress. ${ }^{[40]}$ It has been well documented that Calendula extract showed anti-genotoxicity and ameliorative effect against hepatotoxicity induced by aflatoxin due to high percentage of total PhCs. ${ }^{[6,41]}$ The effect of herbal agents has been summarized in Table 1.

\section{MICRONUTRIENTS (VITAMINS AND MINERALS)}

Vitamin $B_{12}$ (cyanocobalamin) molecule contains a cobalt complex, it is known as cobalamin. Molecular weight of vitamin $B_{12}$ is the highest among all vitamins; therefore, it is known to accumulate at high levels in the liver. Vitamin $B_{12}$ is a complex organometallic cofactor associated with three subfamilies of enzymes: The adenosylcobalamin-dependent isomerases, the methyl cobalamin-dependent methyltransferases, and the dehalogenases. ${ }^{[42]}$ In chronic feeding regimen without a methyl-donor, vitamin $\mathrm{B}_{12}$ may lead to the development of HCC. ${ }^{[43 \mid}$ Previous studies reported that vitamin $B_{12}$ showed

Table 1: Effect of herbal agents against hepatic disorders

\begin{tabular}{|c|c|c|c|c|}
\hline Name & Family & Constituents & Mechanism of action & Major effect \\
\hline $\begin{array}{l}\text { Silybum marianum } \\
\text { (Silymarin) }\end{array}$ & Asteraceae & Silibinin & $\begin{array}{l}\text { Inhibit GSH depletion and genotoxicity } \\
\text { Inhibited telomerase activity in HCC }\end{array}$ & Antioxidant \\
\hline $\begin{array}{l}\text { Glycyrrhiza glabra } \\
\text { (Liquorice) }\end{array}$ & Fabaceae & $\begin{array}{l}\text { Glycyrrhetic } \\
\text { acid }\end{array}$ & $\begin{array}{l}\text { Enhance GSH formation } \\
\text { Induce apoptosis in hepatic cancer }\end{array}$ & Anti-hepatocarcinogenesis \\
\hline Panax ginseng & Araliaceae & Ginsenosides & $\begin{array}{l}\text { Improve GSH synthesis } \\
\text { Enhance apoptosis in HCC }\end{array}$ & Hepatorenoprotective effect \\
\hline Ginkgo biloba & Ginkgoaceae & Polyphenols & $\begin{array}{l}\text { Free radical scavenger } \\
\text { Prevention of tumor initiation }\end{array}$ & Antioxidant \\
\hline $\begin{array}{l}\text { Taraxacum officinale } \\
\text { (Dandelion) }\end{array}$ & Asteraceae & Taraxacin & $\begin{array}{l}\text { Enhance mRNA expression of hepatic antioxidant enzymes } \\
\text { Prevention of tumor initiation }\end{array}$ & Anti-fibrotic effect \\
\hline $\begin{array}{l}\text { Allium sativum } \\
\text { (Garlic) }\end{array}$ & Amaryllidaceae & Allicin & $\begin{array}{l}\text { Modulation of p53 gene } \\
\text { Delay or arrest of the tumor development }\end{array}$ & Anticancer \\
\hline $\begin{array}{l}\text { Curcuma longa } \\
\text { (Turmeric) }\end{array}$ & Zingiberaceae & $\begin{array}{l}\text { Curcumin I, } \\
\text { II, and III }\end{array}$ & $\begin{array}{l}\text { Suppresses the activation of nuclear factor kappa B } \\
\text { Prevention of tumor initiation }\end{array}$ & Anticancer and antioxidant \\
\hline $\begin{array}{l}\text { Colchicum } \\
\text { autumnale }\end{array}$ & Colchicaceae & Colchicine & $\begin{array}{l}\text { Inhibition of cellular mitosis } \\
\text { Delay or arrest of the tumor development }\end{array}$ & Anti-tumor anti-fibrotic agent \\
\hline Thymus vulgaris & Lamiaceae & Thymol & $\begin{array}{l}\text { Increase GSH synthesis } \\
\text { Prevention of tumor initiation }\end{array}$ & Antioxidant, antimicrobial \\
\hline Calendula officinalis & Asteraceae & Triterpenoids & $\begin{array}{l}\text { Enhance antioxidant enzymes } \\
\text { Prevention of tumor initiation }\end{array}$ & $\begin{array}{l}\text { Antioxidant, } \\
\text { anti-inflammatory }\end{array}$ \\
\hline
\end{tabular}

GSH: glutathione; HCC: hepatocellular carcinoma 
hepatoprotective effect against dimethyl nitrosamine in intoxicated rats. Moreover, vitamin $\mathrm{B}_{12}$ suppresses genetic expression of $\alpha$-smooth muscle actin and heat-shock protein 47 , which are markers of liver fibrosis. ${ }^{[44]}$

Vitamin C (ascorbic acid) is one of the most required nutrients for a variety of biological functions. The health-promoting effects of vitamin $\mathrm{C}$ can be attributed to its biological functions as a cofactor for a number of enzymes, most notably hydroxylases involved in collagen synthesis and as a water-soluble antioxidant. ${ }^{[45]}$ However, it can exert its antioxidant properties in both aqueous and non-aqueous environments. ${ }^{[46]}$ Vitamin $C$ is able to decrease hepatic apoptosis and necrosis against cholestatic liver injury in experimental animals. ${ }^{[47]}$

Vitamin $E$ ( $\alpha$-tocopherol) is a potent lipid-soluble and chain-breaking antioxidant required nutrient for humans because it is necessary for the prevention of several symptoms, including peripheral neuropathy and hemolytic anemia. ${ }^{[48]}$ It plays a significant role in preventing or minimizing peroxidation damage in biological systems. ${ }^{[4]}$ Supplementation with vitamin E inhibits DNA damage due to free radical scavenging activity and its exerting anti-cytotoxicity and anti-genotoxicity. ${ }^{[50,51]}$ Moreover, $\alpha$-tocopherol showed hepatoprotective activity against cisplatin-induced oxidative stress, which may be attributed to down-regulations of NADPH oxidase gene expression..$^{[52]}$

Zinc $(\mathrm{Zn})$ is an essential trace element with various biological effects, depending on its catalytic and structural role in an enormous number of enzymes and "Zn-finger" proteins. ${ }^{[53]}$ $\mathrm{Zn}$ ions $\left(\mathrm{Zn}^{2+}\right)$ control cell proliferation, differentiation, and have a role in both apoptotic and necrotic cell death. ${ }^{.54]} \mathrm{Zn}$ also has anti-oxidative and anti-inflammatory properties and it postulates hepatonephroprotective effect due to its antioxidant, anti-apoptotic, and anti-inflammatory properties against cadmium-induced hepatotoxicity and reduction of metal accumulation in the organism, which may lead to nephrotoxicity. ${ }^{[55,56]}$

The naturally occurring element selenium (Se) plays a major role in a wide variety of biological processes in mammals. Se acts as one of the major components due to its low molecular weight as well as its presence within at least 25 proteins, named selenoproteins, in the form of the amino acid selenocysteine, which is incorporated during translation and is directly involved in redox catalysis. ${ }^{[57]}$ Although the function of most selenoproteins is still unknown, thioredoxin reductase, GSH peroxidases, and thyroid hormone deiodinases are well described as selenoproteins, which is involved in maintaining the cell reduction-oxidation balance and thyroid hormone metabolism. ${ }^{[58]}$ Se administration increases the antioxidant capacity of several intracellular systems. In addition, Se showed hepatoprotective effect against malathion-induced liver injury and diabetic rats. ${ }^{[59,60]}$ Table 2 demonstrated the effect of micronutrients on hepatic lesions.

\section{DIETARY SUPPLEMENTS}

$\mathrm{N}$-acetyl cysteine (NAC) is a derivative of the sulfur-containing amino acid cysteine and an intermediary (along with glutamic acid and glycine) in the conversion of cysteine to GSH. Oral NAC administration leads to an increase in intracellular cysteine and GSH levels. ${ }^{[61]}$ NAC is the primary antidote for acetaminophen-induced hepatotoxicity. ${ }^{[62]}$ NAC is able to inhibit genotoxicity due to reactive oxygen species (ROS), protect DNA and nuclear enzymes, and prevent the formation of carcinogen-DNA adducts. ${ }^{|63|}$ NAC succeeded in the treatment of severe hepatic injury induced by a dietary fitness supplement. ${ }^{[64]}$

Alpha lipoic acid (ALA) influences oxidative status by scavenging ROS, regenerating endogenous antioxidants, repairing oxidative damage, and chelating metal ions. ${ }^{\text {[65] }}$ ALA has been proven to be a natural, yet very powerful free radical scavenger and antioxidant. ALA has a protective effect against $\mathrm{CCl}_{4}$-induced hepatotoxicity and prevents against liver fibrosis due to inhibition of transforming growth factor (TGF)/ platelet-derived growth factor-stimulated HSCs activation and ROS generation. . $^{[6-68]}$

L-carnitine (CAR) is a conditionally essential nutrient, synthesized endogenously from lysine and methionine in the liver, kidney, and brain and it induces its effects on both fat and glucose metabolism. ${ }^{[69]}$ CAR binds to fatty acyl-coenzyme $A$ and regulates their transport into mitochondrial matrix for $\beta$-oxidation. L-CAR is a superoxide scavenger, antioxidant, and DNA cleavage protector. ${ }^{\left[{ }^{[70]} \mathrm{L}-\mathrm{CAR}\right.}$ has shown a protective effect against radiation-induced

Table 2: Effect of micronutrients against hepatic injury

\begin{tabular}{|c|c|c|}
\hline Name & Mechanism of action & Major effect \\
\hline Vitamin $B_{12}$ & $\begin{array}{l}\text { Suppresses genetic expression } \\
\text { of } \alpha \text {-smooth muscle actin and } \\
\text { heat-shock protein } 47 \\
\text { Inhibit hepatic fibrosis }\end{array}$ & $\begin{array}{l}\text { Hepatoprotective } \\
\text { effect }\end{array}$ \\
\hline Vitamin C & $\begin{array}{l}\text { Free radical scavenger } \\
\text { Prevention of tumor initiation }\end{array}$ & $\begin{array}{l}\text { Antioxidant, } \\
\text { anti-apoptosis }\end{array}$ \\
\hline Vitamin $\mathrm{E}$ & $\begin{array}{l}\downarrow \text { Genetic expression NADPH, } \\
\text { DNA damage } \\
\text { Prevention of tumor initiation }\end{array}$ & $\begin{array}{l}\text { Anti-cytotoxicity and } \\
\text { anti-genotoxicity }\end{array}$ \\
\hline Zinc & $\begin{array}{l}\text { Free radical scavenger, control } \\
\text { cell proliferation } \\
\text { Prevention of tumor initiation }\end{array}$ & $\begin{array}{l}\text { Anti-inflammatory, } \\
\text { anti-apoptosis }\end{array}$ \\
\hline Selenium & $\begin{array}{l}\text { Catalysis of redox reaction } \\
\text { Prevention of tumor initiation }\end{array}$ & Antioxidant \\
\hline
\end{tabular}


organotoxicity via induction of endogenous antioxidants. ${ }^{[71]}$ Reduction of concentration of CAR in blood and tissues is accompanied with hyperlipidemic condition. ${ }^{[72]}$ It has been well reported that hepatoprotective effect of L-CAR against $\mathrm{CCl}_{4}$-induced hepatotoxicity is due to significant increase of GSH level. ${ }^{\text {[3] }}$

Lycopene is the red pigment of tomatoes. Lycopene concentration in human serum tends to be higher than those of all other carotenoid pigments. ${ }^{[74 \mid}$ Lycopene showed potent anti-inflammatory effects through its action as an antioxidant and free radical scavenger, which may reduce cellular damage. ${ }^{[75]}$ It plays a crucial role in the protection of cell membranes from lipid peroxidation by neutralizing hydroxyl radicals and may bind to DNA, promoting further protection beyond antioxidant activity. ${ }^{[76]}$ Lycopene demonstrated potential beneficial effects against oxidative stress. These beneficial functions are due to enhancement of cellular gap junction communication, induction of phase II enzymes through activation of the antioxidant response element of transcription system, and suppression of insulin-like growth factor-1-stimulated cell proliferation. Its effects also include anti-angiogenesis, inhibition of cell proliferation, and induction of apoptosis. ${ }^{\text {[7] }}$ Lycopene showed potent protective effect against hepatic steatosis in knockout mice. ${ }^{[78]}$

S-adenosyl-1-methionine (SAMe) is an endogenous agent that is a critical precursor for transmethylation and transsulfuration reactions. SAMe plays an important role such as a cofactor for many transmethylation reactions of amino acids, proteins, nucleotides, and neurotransmitters and a vital precursor for the transsulfuration pathway that ultimately generates GSH. ${ }^{[79]}$ SAMe has potent activity against acetaminophen-induced hepatotoxicity as compared to NAC. ${ }^{[80]}$ SAMe reduced the cytotoxicity of other hepatotoxicants such as carbon tetrachloride, which may lead to liver fibrosis and alcohol-mediated damage..$^{[81]}$ SAMe was reported to protect liver against hepatic injury and fibrosis through the inhibition of oxidative stress and HSCs formation due to activation of Smad7 (an inhibitor of TGF-beta signaling; regulator of hepatic fibrosis) messenger RNA expression. ${ }^{[82]}$

Whey protein concentrates (WPCs) are heterogeneous compounds obtained from milk after casein precipitation at $\mathrm{pH}$ 4.6. ${ }^{[83]}$ WPCs play an important biological role since they act as antioxidants, antihypertensive and anti-tumor, hypolipidemic and antiviral, antibacterial, and chelating agents. WPCs counteract oxidative stress and DNA damage in rats that fed an aflatoxin-contaminated diet. ${ }^{[84-89]}$ The effect of various supplements has been depicted in Table 3 .
Table 3: Effect of dietary supplement against hepatotoxicity and hepatic cancer

\begin{tabular}{|c|c|c|}
\hline Name & Mechanism of action & Use \\
\hline $\begin{array}{l}\mathrm{N} \text {-acetyl } \\
\text { cysteine }\end{array}$ & $\begin{array}{l}\text { Increase intracellular cysteine and } \\
\text { GSH levels } \\
\text { Prevention of tumor initiation }\end{array}$ & $\begin{array}{l}\text { Antidote for } \\
\text { acetaminophen- } \\
\text { induced } \\
\text { hepatotoxicity }\end{array}$ \\
\hline $\begin{array}{l}\text { Alpha lipoic } \\
\text { acid }\end{array}$ & $\begin{array}{l}\text { Inhibition of TGF/PDGF-(HSC) } \\
\text { Prevention of tumor initiation and } \\
\text { hepatic fibrosis }\end{array}$ & Antioxidant \\
\hline L-carnitine & $\begin{array}{l}\text { Superoxide scavenger, and DNA } \\
\text { cleavage protector } \\
\text { Prevention of tumor initiation }\end{array}$ & Antioxidant \\
\hline Lycopene & $\begin{array}{l}\text { Suppression of insulin-like growth } \\
\text { factor-1-stimulated cell proliferation } \\
\text { Prevention of tumor initiation and } \\
\text { hepatic fibrosis }\end{array}$ & Antioxidant \\
\hline $\begin{array}{l}\text { S-adenosyl-I- } \\
\text { methionine }\end{array}$ & $\begin{array}{l}\text { Cofactor for amino acids, inhibition } \\
\text { of HSC }\end{array}$ & Antioxidant \\
\hline $\begin{array}{l}\text { Whey protein } \\
\text { concentrates }\end{array}$ & $\begin{array}{l}\text { Free radical scavenger } \\
\text { Prevention of tumor initiation }\end{array}$ & $\begin{array}{l}\text { Antioxidants, } \\
\text { hypolipidemic } \\
\text { agent }\end{array}$ \\
\hline
\end{tabular}

GSH: glutathione; TGF: transforming growth factor; PDGF: platelet-derived growth factor; HSC: hepatic stellate cell

It can be concluded that natural bioactive compounds are promising candidate in the treatment and prevention of hepatic injury as well as HCC. The effects may be due to their anti-oxidative properties, modulatory effects in several cytokines, and anti-genotoxic efficacy. The current article highlights on the potential mechanism of the action of natural compounds against hepatotoxicity and suggests further studies for developing novel therapeutic tools in the treatment of hepatic lesions.

\section{Financial support and sponsorship}

Nil.

\section{Conflict of interest}

There is no conflict of interest.

\section{REFERENCES}

1. Loguercio C, Federico A. Oxidative stress in viral and alcoholic hepatitis. Free Radic Biol Med 2003;34:1-10.

2. Vitaglione P, Morisco F, Caporaso N, Fogliano V. Dietary antioxidant compounds and liver health. Crit Rev Food Sci Nutr 2004; $44: 575-86$.

3. Jemal A, Bray F, Center MM, Ferlay J, Ward E, Forman D. Global cancer statistics. CA Cancer J Clin 2011;61:69-90.

4. Ko WS, Hsu SL, Chyau CC, Chen KC, Peng RY. Compound Cordyceps TCM-700C exhibits potent hepatoprotective capability in animal model. Fitoterapia 2010;81:1-7.

5. Somasundaram A, Karthikeyan R, Velmurugan V, Dhandapani B, Raja M. Evaluation of hepatoprotective activity of Kyllinga nemoralis (Hutch and Dalz) rhizomes. J Ethnopharmacol 2010;127:555-7.

6. Hamzawy MA, El-Denshary ES, Hassan NS, Mannaa FA, Abdel-Wahhab MA. Dietary supplementation of Calendula officinalis counteracts the oxidative stress and liver damage resulted from aflatoxin. ISRN Nutr 2013;2013:538427. 
7. Bravo L. Polyphenols: chemistry, dietary sources, metabolism, and nutritional significance. Nut Rev 1998;56:317-33.

8. Yamashita H, Goto M, Matsui-Yuasa I, Kojima-Yuasa A. Ecklonia cava polyphenol has a protective effect against ethanol-induced liver injury in a cyclic AMP-dependent manner. Mar Drugs 2015;13:3877-91.

9. Manach C, Scalbert A, Morand C, Rémésy C, Jiménez L. Polyphenols: food sources and bioavailability. Am J Clin Nutr 2004;79:727-47.

10. Wunjuntuk K, Kettawan A, Charoenkiatkul S, Rungruang T. Parboiled germinated brown rice protects against $\mathrm{CCl}_{4}$-induced oxidative stress and liver injury in rats. J Med Food 2015; Epub ahead of print.

11. Rice-Evans CA, Miller NJ, Paganga G. Structure-antioxidant activity relationships of flavonoids and phenolic acids. Free Radic Biol Med 1996;20:933-56.

12. Xiao ZP, Peng ZY, Peng MJ, Yan WB, Ouyang YZ, Zhu HL. Flavonoids health benefits and their molecular mechanism. Mini Rev Med Chem 2011;11:169-77.

13. Donfack JH, Simo CC, Ngameni B, Tchana AN, Kerr PG, Finzi PV, Vidari G, Giardina S, Buonocore D, Ngadjui BT, Moundipa PF, Marzatico F. Antihepatotoxic and antioxidant activities of methanol extract and isolated compounds from Ficus chlamydocarpa. Nat Prod Commun 2010;5:1607-12

14. Shaker E, Mahmoud H, Mnaa S. Silymarin, the antioxidant component and Silybum marianum extracts prevent liver damage. Food Chem Toxicol 2010;48:803-6.

15. Alcaraz-Contreras Y, Mendoza-Lozano RP, Martínez-Alcaraz ER, Martínez-Alfaro M, Gallegos-Corona MA, Ramírez-Morales MA, Vázquez-Guevara MA. Silymarin and dimercaptosuccinic acid ameliorate lead-induced nephrotoxicity and genotoxicity in rats. Hum Exp Toxicol 2015; Epub ahead of print.

16. Fiore C, Eisenhut M, Ragazzi E, Zanchin G, Armanini D. A history of the therapeutic use of liquorice in Europe. J Ethnopharmacol 2005;99:317-24

17. Nakagawa K, Hosoe K, Hidaka T, Nabae K, Kawabe M, Kitano M. Inhibition by licorice flavonoid oil of glutathione $\mathrm{S}$-transferase-positive foci in the medium-term rat hepatocarcinogenesis bioassay. Nut Res 2010;30:74-81

18. Orazizadeh M, Fakhredini F, Mansouri E, Khorsandi L. Effect of glycyrrhizic acid on titanium dioxide nanoparticles-induced hepatotoxicity in rats. Chem Biol Interact 2014;220:214-21.

19. Abdel-Wahhab MA, Hassan NS, El-Kady AA, Khadrawy YA, El-Nekeety AA, Mohamed SR, Sharaf HA, Mannaa FA. Red ginseng extract protects against aflatoxin B1 and fumonisins-induced hepatic pre-cancerous lesions in rats. Food Chem Toxicol 2010;48:733-42.

20. El Denshary ES, Al-Gahazali MA, Mannaa FA, Salem HA, Hassan NS, Abdel-Wahhab MA. Dietary honey and ginseng protect against carbon tetrachloride-induced hepatonephrotoxicity in rats. Exp Toxicol Pathol 2012;64:753-60.

21. He SX, Luo JY, Wang YP, Wang YL, Fu H, Xu JL, Zhao G, Liu EQ. Effects of extract from Ginkgo biloba on carbon tetrachloride-induced liver injury in rats. World J Gastroenterol 2006;12:3924-8.

22. Schiborr C, Eckert P, Weissenberger J, Muller E, Schwamm D, Grune T, Rimbach G, Frank J. Cardiac oxidative stress and inflammation are similar in SAMP8 and SAMR1 mice and unaltered by curcumin and Ginkgo biloba extract intake. Curr Pharm Biotechnol 2010;11:861-7.

23. Yan Z, Fan R, Yin S, Zhao X, Liu J, Li L, Zhang W, Ge L. Protective effects of Ginkgo biloba leaf polysaccharide on nonalcoholic fatty liver disease and its mechanisms. Int J Biol Macromol 2015;80:573-80.

24. Koh PO. Gingko biloba Extract (EGb 761) Prevents cerebral ischemia-induced p70S6 Kinase and S6 Phosphorylation. Am J Chin Med 2010;38:727-34

25. Gulfraz M, Ahamd D, Ahmad MS, Qureshi R, Mahmood RT, Jabeen N, Abbasi KS. Effect of leaf extracts of Taraxacum officinale on $\mathrm{CCl}_{4}$ induced hepatotoxicity in rats, in vivo study. Pak J Pharm Sci 2014;27:825-9.

26. Cho SY, Park JY, Park EM, Choi MS, Lee MK, Jeon SM, Jang MK,
Kim MJ, Park YB. Alternation of hepatic antioxidant enzyme activities and lipid profile in streptozotocin-induced diabetic rats by supplementation of dandelion water extract. Clin Chim Acta 2002;317:109-17.

27. Colle D, Arantes LP, Gubert P, da Luz SC, Athayde ML, Teixeira Rocha JB, Soares FA. Antioxidant properties of Taraxacum officinale leaf extract are involved in the protective effect against hepatotoxicity induced by acetaminophen in mice. J Med Food 2012;15:549-56.

28. Domitrović R, Jakovac H, Romić Z, Rahelić D, Tadić Z. Antifibrotic activity of Taraxacum officinale root in carbon tetrachloride-induced liver damage in mice. J. Ethnopharmacol 2011;130:569-77.

29. Rana SV, Pal R, Vaiphei K, Sharma SK, Ola RP. Garlic in health and disease. Nutr Res Rev 2011;24:60-71.

30. Chu YL, Ho CT, Chung JG, Raghu R, Lo YC, Sheen LY. Allicin induces anti-human liver cancer cells through the p53 gene modulating apoptosis and autophagy. J Agric Food Chem 2013;61:9839-48.

31. Reyes-Gordillo K, Segovia J, Shibayama M, Vergara P, Moreno MG, Muriel P. Curcumin protects against acute liver damage in the rat by inhibiting NF-[kappa] B, proinflammatory cytokines production and oxidative stress. Biochim Biophys Acta 2007;1770:989-96.

32. Soliman MM, Baiomy AA, Yassin MH. Molecular and histopathological study on the ameliorative effects of curcumin against lead acetate-induced hepatotoxicity and nephrotoxicity in Wistar rats. Biol Trace Elem Res 2015;167:91-102.

33. Le Marchand Y, Singh A, Assimacopoulos-Jeannet F, Orci L, Rouiller C, Jeanrenaud B. A role for the microtubular system in the release of very low-density lipoproteins by perfused mouse livers. J Biol Chem 1973;248:6862-70.

34. Ludford RJ. Colchicine in the experimental chemotherapy of cancer. J Natl Cancer Inst 1945;6:89.

35. Lu Y, Chen J, Wang J, Li CM, Ahn S, Barrett CM, Dalton JT, Li W, Miller DD. Design, synthesis, and biological evaluation of stable colchicine binding site tubulin inhibitors as potential anticancer agents. J Med Chem 2014;57:7355-66.

36. Muntoni S, Rojkind M. Colchicine reduces procollagen III and increases pseudocholinesterase in chronic liver disease. World $J$ Gastroenterol 2010;16:2889-94

37. Hamzawy MA, El-Denshary ES, Hassan NS, Manaa F, Abdel-Wahhab MA. Antioxidant and hepatorenoprotective effects of Thyme vulgaris extract in rats during aflatoxicosis. Glob J Pharmacol 2012;6:106-17.

38. Chizzola R, Michitsch H, Franz C. Antioxidative properties of Thymus vulgaris leaves: comparison of different extracts and essential oil chemotypes. J Agric Food Chem 2008;56:6897-904.

39. Re TA, Mooney D, Antignac E, Dufour E, Bark I, Srinivasan V, Nohynek G. Application of the threshold of toxicological concern approach for the safety evaluation of calendula flower (Calendula officinalis) petals and extracts used in cosmetic and personal care products. Food Chem Toxicol 2009;47:1246-54.

40. Fonseca YM, Catini CD, Vicentini FT, Cardoso JC, Cavalcanti De Albuquerque Junior RL, Vieira Fonseca MJ. Efficacy of marigold extract loaded formulations against UV-induced oxidative stress. J Pharm Sci 2011;100:2182-93.

41. Abdel-Azim SH, Hassan AM, El-Denshary ES, Hamzawy MA, Manaa FA, Abdel-Wahhab MA. Ameliorative effects of thyme and calendula extracts alone or in combination against aflatoxins-induced oxidative stress and genotoxicity in rat liver. Cytotechnology 2014;66:457-70.

42. Banerjee R, Ragsdale SW. The many faces of Vitamin B12: catalysis by cobalamin-dependent enzymes 1. Ann Rev Biochem 2003;72:209-47.

43. Asada K, Kotake Y, Asada R, Saunders D, Broyles RH, Towner RA, Fukui H, Floyd RA. LINE-1 hypomethylation in a choline-deficiency-induced liver cancer in rats: dependence on feeding period. J Biomed Biotechnol 2006;2006:17142.

44. Isoda K, Kagaya N, Akamatsu S, Hayashi S, Tamesada M, Watanabe A, 
Kobayashi M, Tagawa Y, Kondoh M, Kawase M. Hepatoprotective effect of Vitamin B12 on dimethylnitrosamine-induced liver injury. Biol Pharm Bull 2008;31:309-11.

45. Sowell J, Frei B, Stevens JF. Vitamin C conjugates of genotoxic lipid peroxidation products: structural characterization and detection in human plasma. Proc Natl Acad Sci U S A 2004;101:17964.

46. Majamaa K, Günzler V, Hanauske-Abel HM, Myllyl R, Kivirikko KI. Partial identity of the 2-oxoglutarate and ascorbate binding sites of prolyl 4-hydroxylase. J Biol Chem 1986;261:7819.

47. Yu SJ, Bae S, Kang JS, Yoon JH, Cho EJ, Lee JH, Kim YJ, Lee WJ, Kim CY, Lee HS. Hepatoprotective effect of Vitamin C on lithocholic acid-induced cholestatic liver injury in Gulo(-/-) mice. Eur J Pharmacol 2015;762:247-55.

48. Traber MG, Stevens JF. Vitamins C and E: beneficial effects from a mechanistic perspective. Free Radic Biol Med 2011;51:1000-13.

49. Packer L, Landvik S. Vitamin E in biological systems. Adv Exp Med Biol 1990;264:93.

50. Abd Hamid NA, Hasrul MA, Ruzanna RJ, Ibrahim IA, Baruah PS, Mazlan M, Yusof YA, Ngah WZ. Effect of Vitamin E (Tri $\left.E^{\circledR}\right)$ on antioxidant enzymes and DNA damage in rats following eight weeks exercise. Nut $J$ 2011;10:37.

51. Ayed Boussema I, Abassi H, Bouaziz C, Hlima WB, Ayed Y, Bacha H. Antioxidative and antigenotoxic effect of Vitamin E against patulin cytotoxicity and genotoxicity in HepG2 cells. Environ Toxicol 2011;28:299-306.

52. Palipoch S, Punsawad C, Koomhin P, Suwannalert P. Hepatoprotective effect of curcumin and alpha-tocopherol against cisplatin-induced oxidative stress. BMC Complement Altern Med 2014;14:111.

53. Nakata E, Liew FF, Uwatoko C, Kiyonaka S, Mori Y, Katsuda Y, Endo M, Sugiyama H, Morii T. Zinc-Finger proteins for site-specific protein positioning on DNA origami structures. Angew Chem 2012;51:2421-4.

54. Formigari A, Irato P, Santon A. Zinc, antioxidant systems and metallothionein in metal mediated-apoptosis: biochemical and cytochemical aspects. Comp Biochem Physiol C Toxicol Pharmacol 2007; 146:443-59.

55. Rogalska J, Pilat-Marcinkiewicz B, Brzóska MM. Protective effect of zinc against cadmium hepatotoxicity depends on this bioelement intake and level of cadmium exposure: a study in a rat model. Chem Biol Interact 2011;193:191-203.

56. Malhotra A, Dhawan DK. Current view of zinc as a hepatoprotective agent in conditions of chlorpyrifos induced toxicity. Pestic Biochem Physiol 2014;112:1-6.

57. Romero H, Zhang Y, Gladyshev VN, Salinas G. Evolution of selenium utilization traits. Genome Biol 2005;6:R66.

58. Arbogast S, Ferreiro A. Selenoproteins and protection against oxidative stress: selenoprotein $\mathrm{N}$ as a novel player at the crossroads of redox signaling and calcium homeostasis. Antioxid Redox Signal 2010;12:893-904.

59. Aboul-Soud MA, Al-Othman AM, El-Desoky GE, Al-Othman ZA, Yusuf K, Ahmad J, Al-Khedhairy AA. Hepatoprotective effects of Vitamin E/selenium against malathion-induced injuries on the antioxidant status and apoptosis-related gene expression in rats. J Toxicol Sci 2011;36:285-96.

60. Zou C, Qiu Q, Chen H, Dou L, Liang J. Hepatoprotective effects of selenium during diabetes in rats. Hum Exp Toxicol 2015; Epub ahead of print.

61. Ahmed HH, El-Aziem SH, Abdel-Wahhab MA. Potential role of cysteine and methionine in the protection against hormonal imbalance and mutagenicity induced by furazolidone in female rats. Toxicology 2008;243:31-42.

62. Parcell S. Sulfur in human nutrition and applications in medicine. Altern Med Rev 2002;7:22-44.

63. De Vries N, De Flora S. N acetyl 1 cysteine. J Cell Biochem 1993;53:270-7.
64. El Rahi C, Thompson-Moore N, Mejia P, De Hoyos P. Successful use of N-Acetylcysteine to treat severe hepatic injury caused by a dietary fitness supplement. Pharmacotherapy 2015;35:e96-101.

65. Biewenga GP, Haenen GR, Bast A. The pharmacology of the antioxidant lipoic acid. Gen Pharmacol 1997;29:315-31.

66. Packer L, Witt EH, Tritschler HJ. Alpha-lipoic acid as a biological antioxidant. Free Radic Biol Med 1995;19:227-50.

67. Hamzawy MA, El-Denshary E, Bahgat A, Abdel-Wahhab MA. Hepatoprotective effect of estradiol and $\alpha$-lipoic acid in rats. Glob $J$ Pharmacol 2014;8:694-702.

68. Foo NP, Lin SH, Lee YH, Wu MJ, Wang YJ. $\alpha$-Lipoic acid inhibits liver fibrosis through the attenuation of ROS-triggered signaling in hepatic stellate cells activated by PDGF and TGF- $\beta$. Toxicology 2011;282:39-46.

69. Ramsay R. The carnitine acyltransferases: modulators of acyl-CoA-dependent reactions. Biochem Soc Trans 2000;28:182-6.

70. Olszowy Z, Plewka A, Czech E, Nowicka J, Plewka D, Nowaczyk G, Kaminski M. Effect of L-carnitine supplementation on xenobiotic-metabolizing hepatic enzymes exposed to methanol. Exp Toxicol Pathol 2006;57:427-35.

71. Mansour HH. Protective role of carnitine ester against radiation-induced oxidative stress in rats. Pharmacol Res 2006;54:165-71.

72. Dayanandan A, Kumar P, Panneerselvam C. Protective role of L-carnitine on liver and heart lipid peroxidation in atherosclerotic rats. $J$ Nut Biochem 2001;12:254-7.

73. Hamzawy MA, El-Denshary E, Bahgat A, Abdel-Wahhab MA. Protective effect of L-carnitine against carbon tetrachloride-induced liver. New Egypt J Med 2009;40:139-49.

74. Khachik F, Carvalho L, Bernstein PS, Muir GJ, Zhao DY, Katz NB. Chemistry, distribution, and metabolism of tomato carotenoids and their impact on human health. Exp Biol Med 2002;227:845-51.

75. Saedisomeolia A, Wood LG, Garg ML, Gibson PG, Wark PA. Lycopene enrichment of cultured airway epithelial cells decreases the inflammation induced by rhinovirus infection and lipopolysaccharide. J Nut Biochem 2009;20:577-85.

76. Subhash K, Bose C, Agrawal BK. Effect of short-term supplementation of tomatoes on antioxidant enzymes and lipid peroxidation in type-II diabetes. Indian J Clin Biochem 2007;22:95-8.

77. Min JR, Lian F, Wang XD. Biological activity of lycopene metabolites: implications for cancer prevention. Nut Rev 2008;66:667-83.

78. Ip BC, Liu C, Lichtenstein AH, von Lintig J, Wang XD. Lycopene and apo-10'-lycopenoic acid have differential mechanisms of protection against hepatic steatosis in $\beta$-carotene-9',10'-oxygenase knockout male mice. J Nutr 2015;145:268-76.

79. Lu SC. Regulation of hepatic glutathione synthesis. Semin Liver Dis 1998;18:331-44.

80. Terneus MV, Kiningham KK, Carpenter AB, Sullivan SB, Valentovic MA. Comparison of S-Adenosyl-L-methionine and N-acetylcysteine protective effects on acetaminophen hepatic toxicity. J Pharmacol Exp Ther 2007;320:99-107.

81. Song Z, Zhou Z, Chen T, Hill D, Kang J, Barve S, McClain C. $\mathrm{S}$-adenosylmethionine (SAMe) protects against acute alcohol induced hepatotoxicity in mice. J Nut Biochem 2003;14:591-7.

82. Guo T, Chang L, Xiao Y, Liu Q. S-adenosyl-L-methionine for the treatment of chronic liver disease: a systematic review and meta-analysis. PLoS One 2015;10:e122124.

83. Parod PW. A role for milk proteins in cancer prevention. Aust J Dairy Technol 1998;53:37-47.

84. Bounous G. Whey protein concentrate (WPC) and glutathione modulation in cancer treatment. Anticancer Res 2000;20:4785-92.

85. Yoo YC, Watanabe S, Watanabe R, Hata K, Shimazaki K, Azuma I. Bovine Lactoferrin and lactoferricin ${ }^{\mathrm{TM}}$ inhibit tumor metastasis in mice. Adv Lacto Res 1998;443:285.

86. Low PP, Rutherfurd KJ, Gill HS, Cross ML. Effect of dietary whey protein concentrate on primary and secondary antibody responses in immunized BALB/c mice. Int Immunopharmcol 2003;3:393-401. 
87. Ajello M, Greco R, Giansanti F, Massucci MT, Antonini G, Valenti P. Anti-invasive activity of bovine lactoferrin towards group A streptococci. Biochem Cell Biol 2002;80:119-24.

88. Weinberg E. The role of iron in cancer. Eur J Cancer Prev 1996;5:19-36.
89. Abdel-Aziem SH, Hassan AM, Abdel-Wahhab MA. Dietary supplementation with whey protein and ginseng extract counteracts oxidative stress and DNA damage in rats fed an aflatoxin-contaminated diet. Mutat Res 2011;723:65-71. 